\title{
Renal Effects and Carcinogenicity of Occupational Exposure to Uranium: A Meta-Analysis
}

\author{
Leonhard Stammler ${ }^{a}$ Andreas Uhlc Benjamin Mayer ${ }^{\mathrm{b}}$ Frieder Keller $^{\mathrm{a}}$ \\ ${ }^{a}$ Nephrology, Department of Internal Medicine 1, and b Institute of Epidemiology and

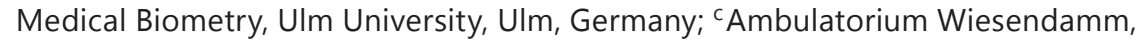 \\ Basel, Switzerland
}

\section{Key Words}

Uranium exposure $\cdot$ Kidney · Carcinogenicity · Meta-analysis · Standardized mortality ratio · Standardized incidence ratio $\cdot$ Biomarker

\section{Abstract}

Purpose: Uranium is a heavy metal with alpha radioactivity. We state the hypothesis that uranium exposure is harmful to human kidneys and carcinogenic to body tissues. Therefore, we review epidemiological studies from people with known long-lasting uranium exposure. Materials and Methods: Three meta-analyses are performed using clinical studies published in the PubMed database and applying RevMan 5.3 from the Cochrane Collaboration to calculate the outcome. The first two meta-analyses examine the standardized mortality ratio (SMR) and the standardized incidence ratio for any cancers of uranium workers who were operating in areas ranging from uranium processing to the assembly of final uranium products. The third meta-analysis evaluates the nephrotoxic risk in uranium workers as well as soldiers and of individuals with exposure to drinking water containing uranium. Results: Overall and contrasting to our hypothesis, the tumor risk is significantly lower for uranium workers than for control groups (SMR $=0.90$ with a $95 \%$ confidence interval of 0.84 to 0.96 ). In addition and also contrasting to our hypothesis, the risk of nephrotoxicity is not increased either. This holds for both the incidence and the mortality due to renal cell carcinoma or due to acute kidney injury or chronic kidney disease. In contrast, a significantly better creatinine clearance is found for the uranium cohort as compared to the control groups (mean difference $=7.66$ with a $95 \%$ confidence interval of 0.12 to 15.2). Conclusion: Our hypothesis that a chronic uranium exposure is associated with an increased risk of cancer mortality or of kidney failure is refuted by clinical data. The decreased risk may result from better medical surveillance of uranium workers. 
Stammler et al.: Renal Effects and Carcinogenicity of Occupational Exposure to Uranium: A Meta-Analysis

\section{Introduction}

In animal studies on the carcinogenicity of uranium, there are several analyses showing evidence of neoplasms [1]. Meta-analysis of animal studies on uranium nephrotoxicity yields controversial results: depending on the dose and the animal race, the major renal events are proteinuria, glycosuria and especially renal tubular degeneration and lesion [2]. Nevertheless, the kidney is a main target of uranium toxicity for various animal species [3].

Uranium is a naturally occurring element. Traces of it can be found in every animate being, ingesting it with their food and water. Three uranium isotopes are encountered in nature, all of them unstable and alpha emitters: $99.27 \%$ of the naturally occurring uranium is U-238 with a radioactive half-life time of 4.47 billion years, $0.72 \% \mathrm{U}-235$ with a half-life of 704 million years, and $0.0055 \%$ U-234 with a half-life of 247,000 years. Enriched uranium has an increased U-235 ratio of $\sim 3 \%$ for nuclear power stations and $\sim 90 \%$ for atomic bombs. Depleted uranium shows a decreased U-235 ratio down to $0.2 \%$ and is of interest due to its high specific weight and shielding capability. Alpha emitters can be shielded by any thin material layer. That is why uranium cannot harm the human body from outside.

It is known that workers in underground uranium mines have a higher lung cancer risk. This is due to the fact that lung cancer risk increases significantly with the radon and silica burden [4] in the air. Radon-222 is the decay product of radium and can be found in the decay series of uranium and thorium, with an alpha-emitting radioactive half-life of 3.8 days. In underground mines, radon- 222 accounts for $54 \%$ of the effective dose for the lung. In contrast, long-lived radioactive dust, which contains radioactive elements with half-lives of more than 100 days, such as uranium, thorium and radium, accounts for just $10 \%$ of the effective dose [5].

Simply put, our purpose was to test the following two hypotheses: (1) chronically elevated uranium exposure is carcinogenic for humans, and (2) chronically elevated uranium exposure harms the human kidney.

\section{Materials and Methods}

To clearly avoid mixed exposure with radon and other radioactive elements rather than mainly uranium-involved exposure, we excluded studies of employees working in uranium mines, nuclear power stations or reprocessing plants. Instead, we focused on areas where uranium is the main pollutant, such as in the areas ranging from uranium ore processing sites to the assembly of the final products.

\section{Uranium Exposure}

The LD50 for acute chemical toxicity of highly soluble uranium compounds is suggested to be $5 \mathrm{~g}$ for oral intake and $1 \mathrm{~g}$ via inhalation [6]. The case outcome of $15 \mathrm{~g}$ orally ingested uranium acetate is acute renal failure with dialysis for 2 weeks, refractory anemia, rhabdomyolysis, myocarditis, liver dysfunction and a paralytic ileus. After 6 months, persistent incomplete Fanconi syndrome remained [7]. The uranium exposure we consider for this meta-analysis is below the acute toxicity but above the normal level. To assess internal uranium exposure, urinary uranium analyses are needed. Only one study performed urinary uranium analysis. At that uranium enrichment plant, $72 \%$ of the tested employees had urinary uranium levels above $10 \mu \mathrm{g} / \mathrm{l}$, of which $15 \%$ were above $150 \mu \mathrm{g} / \mathrm{l}$ [8]. Other different US American uranium mills showed urinary uranium concentrations above $15 \mu \mathrm{g} / \mathrm{l}$ in $25.5 \%$ of tested workers [9]. For comparison, the 95th percentile of urinary uranium for the US population was $0.046 \mu \mathrm{g} / \mathrm{l}$ in the years 1999-2000 [10]. 
Stammler et al.: Renal Effects and Carcinogenicity of Occupational Exposure to Uranium: A Meta-Analysis

Table 1. Clinical studies used for the SMR meta-analysis

\begin{tabular}{|c|c|c|c|c|c|}
\hline Ref. & Country & Work type & $\begin{array}{l}\text { Working } \\
\text { period }\end{array}$ & $\begin{array}{l}\text { Mortality } \\
\text { follow-up }\end{array}$ & Subgroup \\
\hline$[20]$ & France & Uranium metallurgic research & $1950-1968$ & 1968-1990 & \\
\hline [21] & Britain & Nuclear weapons research & $1951-1982$ & Same & Internal uranium exposition \\
\hline [22] & USA & Uranium milling and refining & $1979-2001$ & 1979-2005 & Never worked in underground mines \\
\hline [23] & USA & Nuclear fuel research (mainly uranium) & 1948-1999 & $1948-2008$ & Any internal radiation \\
\hline [24] & USA & Uranium enrichment & $1952-2003$ & Same & \\
\hline [25] & USA & Uranium milling, refining and research & $1943-1949$ & 1943-1979 & $\begin{array}{l}\text { Mortality rates are compared with } \\
\text { surrounding districts if possible; if not, } \\
\text { they are compared with home country } \\
\text { rates }\end{array}$ \\
\hline [26] & USA & Uranium milling, refining and metallurgy & $1942-1966$ & 1942-1993 & \\
\hline [27] & France & Uranium refining and enrichment & $1960-2005$ & $1968-2005$ & \\
\hline [28] & USA & Uranium metallurgy & $1956-1978$ & 1956-1979 & Industrial worker \\
\hline [29] & Germany & Uranium milling and refining & $1946-1989$ & $1970-2008$ & \\
\hline [30] & USA & Uranium enrichment and metallurgy & $1947-1974$ & $1947-1990$ & \\
\hline [31] & Britain & Uranium enrichment & 1946-1995 & Same & Radiation workers \\
\hline [32] & Britain & $\begin{array}{l}\text { Uranium refining and nuclear fuel } \\
\text { production }\end{array}$ & $1946-1995$ & Same & Radiation worker \\
\hline [33] & USA & Uranium enrichment & $1955-1991$ & Same & $\begin{array}{l}\text { Internal radiation exposure was } \\
\text { preferred, missing cancer types are } \\
\text { refilled with the uranium enrichment } \\
\text { subgroup }\end{array}$ \\
\hline$[34]$ & USA & Uranium milling and refining & $\begin{array}{l}1940 / \\
1960-1998\end{array}$ & Same & $\begin{array}{l}\text { Mortality rates are compared with } \\
\text { surrounding districts if possible; if not, } \\
\text { they are compared with home country } \\
\text { rates }\end{array}$ \\
\hline [8] & USA & Uranium enrichment and metallurgy & $1943-1947$ & $1943-1973$ & Alpha and beta chemistry \\
\hline [35] & USA & Uranium enrichment & $1951-1985$ & $1951-2004$ & Hourly paid male worker \\
\hline [36] & USA & $\begin{array}{l}\text { Uranium milling and phosphate fertilizer } \\
\text { production }\end{array}$ & $1953-1976$ & Same & \\
\hline$\overline{[37]}$ & Canada & Uranium milling, refining and enrichment & $1932-1980$ & 1950-1999 & \\
\hline
\end{tabular}

Table 2. Clinical studies used for the SIR meta-analysis

\begin{tabular}{|c|c|c|c|c|c|}
\hline Ref. & Country & Work type & Working period & Follow-up & Subgroup \\
\hline$[28]$ & USA & Uranium metallurgy & $1956-1978$ & $1956-1979$ & Industrial worker \\
\hline$[31]$ & Britain & Uranium enrichment & $1946-1995$ & $1971-1991$ & Radiation workers \\
\hline [37] & Canada & Uranium milling, refining and enrichment & $1932-1980$ & 1969-1999 & \\
\hline
\end{tabular}

\section{Clinical Study Selection}

We searched for published clinical studies in the PubMed database. We also browsed the list of references for suitable studies. The articles had to be written in English or German and there is no annual cut used. The last query at PubMed was December 2014. Search terms for the PubMed database were: uranium kidney, uranium renal, depleted uranium, uranium carcinoma, cancer uranium miner, uranium drinking water, uranium SMR, uranium milling, uranium processing, uranium exposure mortality, uranium water cancer, uranium water risk and nuclear fuel cancer. In total, there were 2,890 hits. Of these hits, we selected cohort studies with information about standardized mortality ratio (SMR; table 1), standardized incidence ratio (SIR; table 2) and cross-sectional studies with information about renal biomarkers (table 3). For the SMR and SIR meta-analysis, we excluded studies of employees 
Stammler et al.: Renal Effects and Carcinogenicity of Occupational Exposure to Uranium: A Meta-Analysis

Table 3. Studies used for the meta-analysis of biomarkers of kidney injury

\begin{tabular}{|c|c|c|c|c|c|}
\hline Ref. & Country & Type of exposure & $\begin{array}{l}\text { Uranium } \\
\text { concentration of } \\
\text { high-exposure } \\
\text { cohort }\end{array}$ & Compared to & $\begin{array}{l}\text { Cutoff high- } \\
\text { exposure cohort }\end{array}$ \\
\hline$[11-17]$ & USA & $\begin{array}{l}\text { Gulf War veterans shot with } \\
\text { uranium ammunition in } \\
\text { friendly fire attacks }\end{array}$ & $\begin{array}{l}0.1-78.125 \mu \mathrm{g} / \mathrm{g} \\
\text { creatinine urine }\end{array}$ & Other Gulf war veterans & $\begin{array}{l}0.1 \mu \mathrm{g} \text { uranium } / \mathrm{g} \\
\text { creatinine in urine }\end{array}$ \\
\hline$[38]$ & Sweden & $\begin{array}{l}\text { Drinking water of private } \\
\text { wells in uranium-rich } \\
\text { bedrocks }\end{array}$ & $\begin{array}{l}0.2-470 \mu \mathrm{g} / \mathrm{l} \\
\text { drinking water }\end{array}$ & $\begin{array}{l}\text { Local controls using } \\
\text { municipal water }\end{array}$ & $\begin{array}{l}0.2 \mu \mathrm{g} \text { uranium/l } \\
\text { drinking water }\end{array}$ \\
\hline [39] & USA & $\begin{array}{l}\text { Uranium milling and } \\
\text { refining worker }\end{array}$ & & $\begin{array}{l}\text { Compared with } \\
\text { equivalent local cement } \\
\text { plant worker }\end{array}$ & \\
\hline$[40]$ & Canada & $\begin{array}{l}\text { Drinking water of private } \\
\text { wells in uranium-rich } \\
\text { bedrocks }\end{array}$ & $\begin{array}{l}2-781 \mu \mathrm{g} / \mathrm{l} \text { drinking } \\
\text { water }\end{array}$ & $\begin{array}{l}\text { Controls using } \\
\text { municipal water }\end{array}$ & $\begin{array}{l}1 \mu g \text { uranium/l } \\
\text { drinking water }\end{array}$ \\
\hline$[41]$ & Canada & $\begin{array}{l}\text { Aboriginal community with } \\
\text { high uranium-containing } \\
\text { drinking water of private } \\
\text { wells }\end{array}$ & $\begin{array}{l}0-845 \mu \mathrm{g} / \mathrm{l} \text { drinking } \\
\text { water }\end{array}$ & $\begin{array}{l}\text { High-excretion cohort } \\
\text { compared to } \\
\text { low-excretion cohort }\end{array}$ & $\begin{array}{l}0.1 \mu \mathrm{g} \text { uranium in } \\
\text { urine excreted/day }\end{array}$ \\
\hline
\end{tabular}

working in uranium mines, nuclear power plants or reprocessing plants. We included only studies of workers operating from uranium processing sites down to the assembly of the final product. A study of workers operating at a phosphate fertilizer production facility is included because their ore has a high uranium content and they had uranium milling activities in the years 1953-1958. The renal biomarker meta-analysis consists of studies of the mentioned uranium workers, studies of soldiers having been targets of friendly fire with uranium projectiles and of individuals with uranium in their drinking water. If possible, mixed genders were used. Where the studies contained subgroups, the subgroup with the highest internal uranium exposure is favored. We selected the study with the longest follow-up if the same cohort was mentioned in different studies. Mortality and incidence rates of the uranium cohort are preferentially compared with mortality rates of surrounding districts.

Over the years 2000-2013, McDiarmid et al. [11-17] published seven different crosssectional studies of a large cohort of approximately 70 US Gulf War veterans with retained uranium shrapnel fragments. We pooled the results of these seven publications and used it as one clinical study for the biomarker meta-analysis.

\section{ICD Codes}

The various clinical studies use different ICD codes for the same cancer topic. Not every cancer type can be inferred from the mentioned cancer topic. Therefore, we unified the ICD codes included for every cancer topic.

\section{RevMan}

We use RevMan 5.3 from the Cochrane Collaboration to calculate the outcome of the meta-analysis. If the heterogeneity test $\left(\mathrm{I}^{2}\right)$ is above $50 \%$, we change fixed effects to random effects. 
Stammler et al.: Renal Effects and Carcinogenicity of Occupational Exposure to Uranium: A Meta-Analysis

Table 4. SMR for uranium-exposed workers

\begin{tabular}{|c|c|c|c|c|c|}
\hline Cause of death & $\begin{array}{l}\text { Included } \\
\text { trials }\end{array}$ & Participants & Statistical method & $\operatorname{SMR}(95 \% \mathrm{CI})$ & $\mathrm{p}$ value \\
\hline All malignant neoplasms & 19 & 71,114 & $\mathrm{M}-\mathrm{H}$, random effects & $0.90(0.84$ to 0.96$)$ & 0.0009 \\
\hline Lung cancer & 17 & 68,056 & $\mathrm{M}-\mathrm{H}$, random effects & $0.95(0.85$ to 1.06$)$ & 0.35 \\
\hline Kidney cancer & 14 & 63,989 & M-H, fixed effect & $0.85(0.66$ to 1.10$)$ & 0.22 \\
\hline Bladder cancer & 13 & 58,359 & M-H, fixed effect & $0.87(0.69$ to 1.10$)$ & 0.24 \\
\hline \multicolumn{6}{|l|}{ All lymphatic and hematopoietic } \\
\hline tissue neoplasms & 9 & 42,578 & M-H, fixed effect & $0.87(0.72$ to 1.06$)$ & 0.16 \\
\hline Leukemia and aleukemia & 14 & 59,416 & M-H, fixed effect & $0.85(0.68$ to 1.06$)$ & 0.16 \\
\hline Chronic lymphocytic leukemia & 4 & 20,154 & $\mathrm{M}-\mathrm{H}$, random effects & $1.00(0.48$ to 2.06$)$ & 0.99 \\
\hline Non-Hodgkin's lymphoma & 15 & 65,951 & $\mathrm{M}-\mathrm{H}$, fixed effect & $0.92(0.73$ to 1.15$)$ & 0.45 \\
\hline Hodgkin's lymphoma & 11 & 51,449 & M-H, fixed effect & $1.22(0.74$ to 2.03$)$ & 0.44 \\
\hline Multiple myeloma & 11 & 41,574 & M-H, fixed effect & $1.11(0.77$ to 1.60$)$ & 0.58 \\
\hline Uterine carcinoma & 5 & 2,427 & M-H, fixed effect & $2.00(0.50$ to 7.99$)$ & 0.33 \\
\hline Ovary cancer & 5 & 2,427 & M-H, fixed effect & $0.82(0.24$ to 2.84$)$ & 1 \\
\hline Breast cancer & 7 & 14,631 & M-H, fixed effect & $1.04(0.59$ to 1.86$)$ & 0.88 \\
\hline Prostate cancer & 10 & 45,610 & M-H, fixed effect & $0.88(0.74$ to 1.05$)$ & 0.14 \\
\hline Liver cancer & 9 & 43,854 & $\mathrm{M}-\mathrm{H}$, fixed effect & $0.59(0.42$ to 0.81$)$ & 0.001 \\
\hline Central nervous system cancer & 13 & 61,485 & M-H, fixed effect & $1.06(0.82$ to 1.36$)$ & 0.65 \\
\hline Bone cancer & 10 & 49,034 & M-H, fixed effect & $0.77(0.34$ to 1.75$)$ & 0.51 \\
\hline Mesothelioma & 5 & 22,863 & $\mathrm{M}-\mathrm{H}$, fixed effect & $1.60(0.73$ to 3.52$)$ & 0.24 \\
\hline Stomach cancer & 14 & 61,450 & $\mathrm{M}-\mathrm{H}$, fixed effect & $0.85(0.72$ to 1.01$)$ & 0.07 \\
\hline Pancreas cancer & 13 & 60,356 & M-H, fixed effect & $0.96(0.80$ to 1.16$)$ & 0.7 \\
\hline Esophagus cancer & 12 & 53,597 & M-H, fixed effect & $0.67(0.51$ to 0.88$)$ & 0.004 \\
\hline Colon cancer & 12 & 63,100 & $\mathrm{M}-\mathrm{H}$, random effects & $0.77(0.65$ to 0.92$)$ & 0.003 \\
\hline Rectum cancer & 12 & 53,597 & $\mathrm{M}-\mathrm{H}$, fixed effect & $0.94(0.74$ to 1.19$)$ & 0.59 \\
\hline Connective tissue cancer & 5 & 33,022 & M-H, fixed effect & $0.83(0.36$ to 1.93$)$ & 0.67 \\
\hline Acute and chronic renal failure & 11 & 50,043 & M-H, fixed effect & $0.87(0.63$ to 1.19$)$ & 0.37 \\
\hline Acute renal failure & 2 & 10,272 & M-H, fixed effect & $0.67(0.11$ to 3.99$)$ & 0.66 \\
\hline Chronic renal failure & 7 & 41,739 & M-H, fixed effect & $0.84(0.57$ to 1.24$)$ & 0.38 \\
\hline
\end{tabular}

$\mathrm{M}-\mathrm{H}=$ Mantel-Haenszel statistics.

\section{Biomarker}

Beta-2 microglobulin (BMG) is part of the major histocompatibility complex. After being freely filtrated, over $99 \%$ is resorbed at the proximal tubule. That is why high urinary BMG values can be a marker of tubular damage. N-acetyl-beta-D-glucosaminidase (NAG) is a lysosomal enzyme found in many different tissues of the body. It cannot pass the glomerular filtration border because of its high molecular weight. Because of its high activity in proximal tubule cells, NAG is a marker of proximal tubular cell necrosis. We checked both markers for possible tubular cell damage.

\section{Results}

\section{Mortality Results}

The meta-analysis presents SMR results of 24 different cancer types and of 3 categories of renal toxicities resulting from a maximum of 71,114 uranium-exposed workers from 19 different clinical studies (table 4). The male proportion of these workers is $93.7 \%$ and therefore very high. 
Stammler et al.: Renal Effects and Carcinogenicity of Occupational Exposure to Uranium: A Meta-Analysis

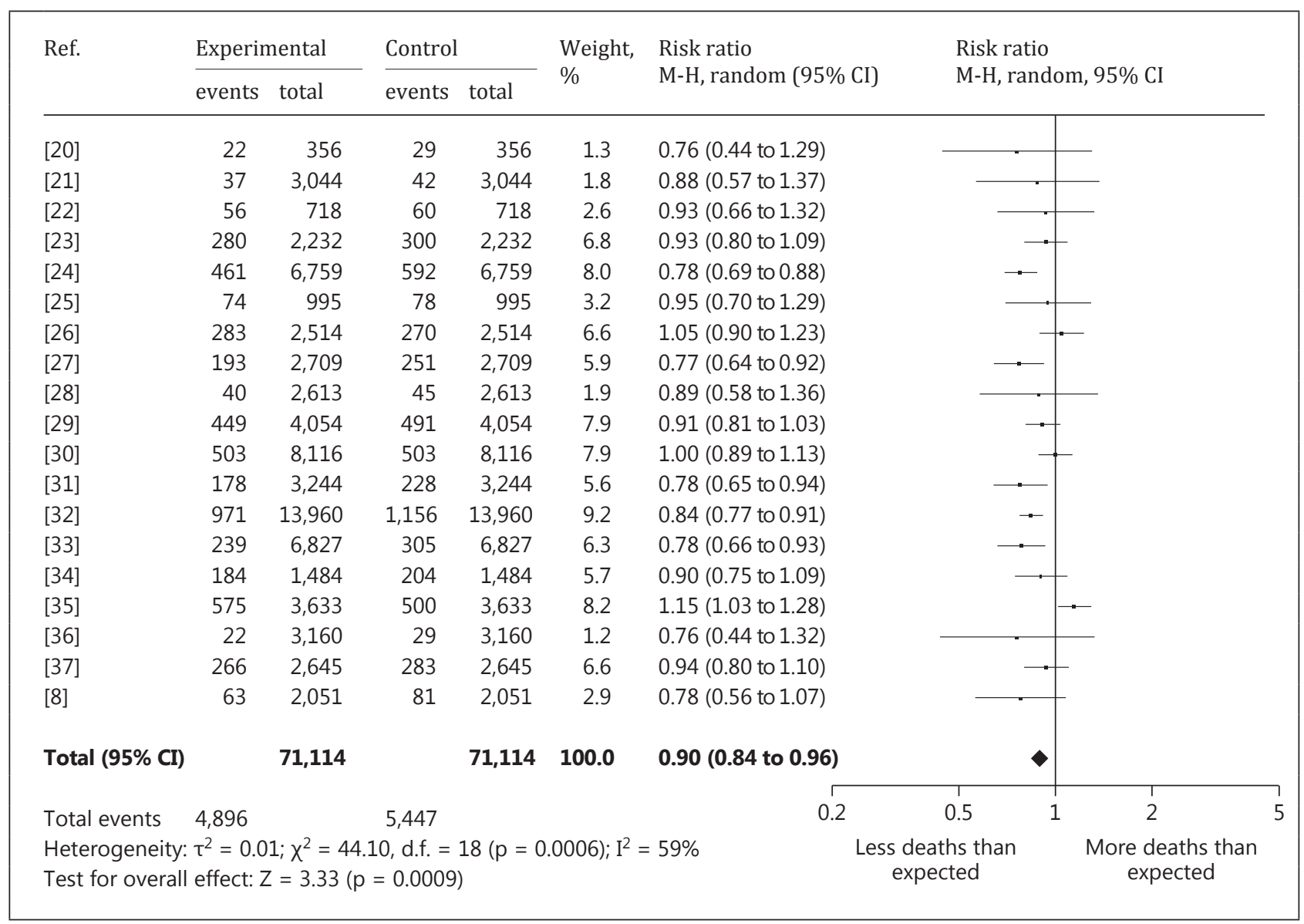

Fig. 1. Forest plot of the SMR of all malignant neoplasms.

Of the 24 different cancer types, 4 show a significantly decreased mortality rate in the uranium-exposed cohort. All malignant neoplasms [SMR $=0.90$ with a $95 \%$ confidence interval (CI) of 0.84 to 0.96 ] (fig. 1), liver cancer (SMR $=0.59,95 \%$ CI 0.42 to 0.81 ), esophageal cancer (SMR $=0.67,95 \%$ CI 0.51 to 0.88 ) and colon cancer (SMR $=0.77,95 \%$ CI 0.65 to 0.92 ) are included. There is no specific cancer type with a significantly increased mortality rate.

Though not being significant, all reviewed mortality rates of kidney (fig. 2) or bladder cancer, as well as acute or chronic renal failure, show decreased mortality rates in the uranium-exposed cohorts.

\section{Cancer Incidence}

Table 5 presents the SIR results of 14 different cancer types with a maximum of 8,858 uranium-exposed participants from 3 different clinical studies. The SIR of all malignant neoplasms reveals a significantly decreased rate (SIR $=0.89,95 \% \mathrm{CI} 0.80$ to 0.98 ). There are no further significant rates.

\section{Biomarker Results}

With a maximum of 563 participants from 5 clinical studies, the renal biomarker metaanalysis has the smallest database (table 6). Nevertheless, there are two significant results.

Despite a significantly higher BMG ( $\mu \mathrm{g} / \mathrm{l})$ value for uranium-exposed persons [mean difference (MD) $=11.38,95 \%$ CI 1.09 to 21.68], it is not a reliable value because it is not age 
Stammler et al.: Renal Effects and Carcinogenicity of Occupational Exposure to Uranium: A Meta-Analysis

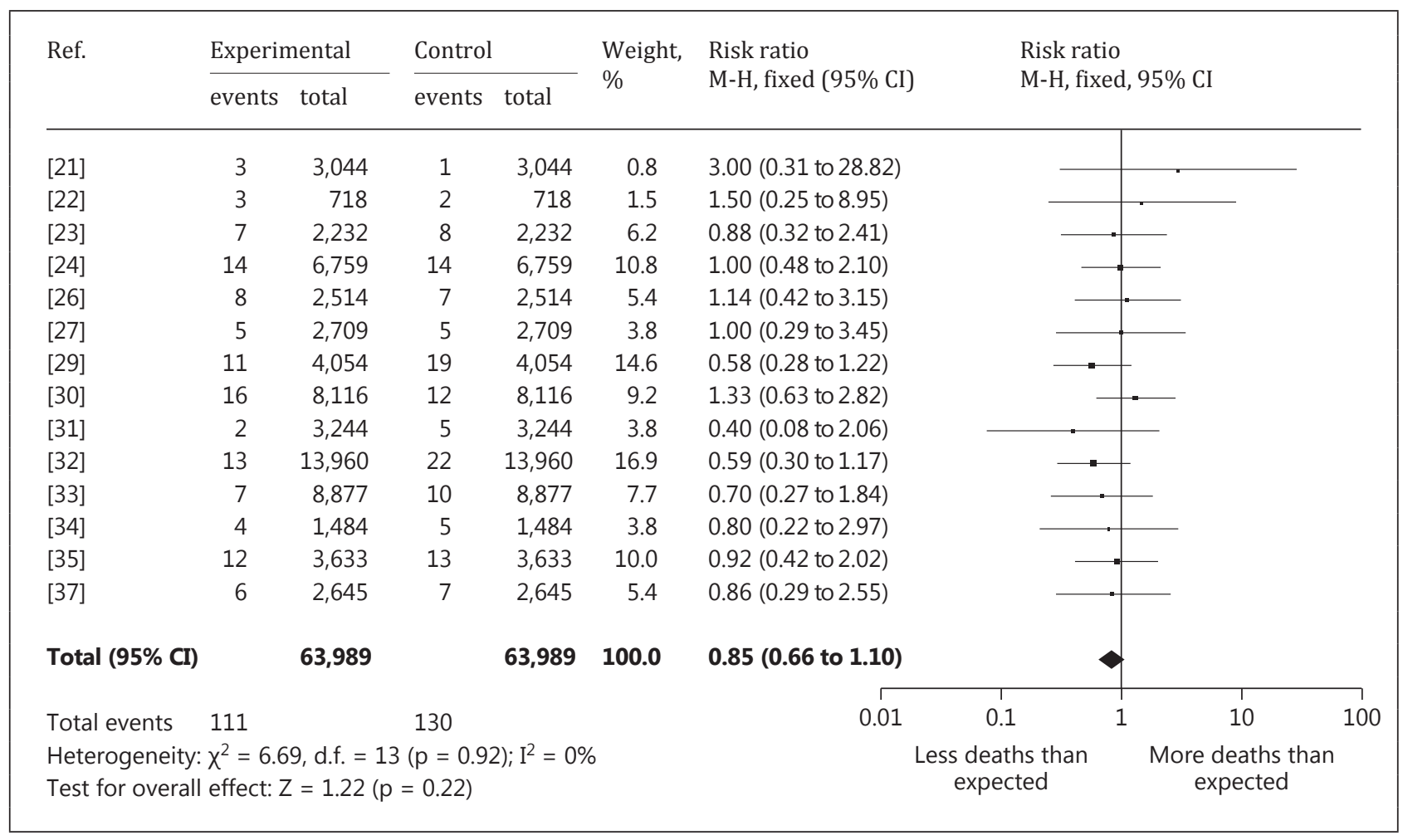

Fig. 2. Forest plot of kidney cancer SMR.

Table 5. SIR of uranium-exposed workers

\begin{tabular}{llllll}
\hline Cancer type & $\begin{array}{l}\text { Included } \\
\text { trials }\end{array}$ & Participants & Statistical method & SIR (95\% CI) \\
& & & & p value \\
All malignant neoplasms & 3 & 8,858 & M-H, fixed effect & $0.89(0.80$ to 0.98$)$ & 0.01 \\
Lung cancer & 3 & 8,858 & M-H, fixed effect & $1.00(0.81$ to 1.23$)$ & 1 \\
Kidney cancer & 3 & 8,858 & M-H, random effects & $0.48(0.22$ to 1.01$)$ & 0.05 \\
Bladder cancer & 3 & 8,858 & M-H, fixed effect & $0.88(0.59$ to 1.32$)$ & 0.53 \\
Leukemia and aleukemia & 2 & 6,244 & M-H, fixed effect & $0.82(0.41$ to 1.67$)$ & 0.59 \\
Non-Hodgkin's lymphoma & 3 & 8,858 & M-H, fixed effect & $0.95(0.52$ to 1.75$)$ & 0.88 \\
Prostate cancer & 2 & 6,151 & M-H, fixed effect & $0.88(0.68$ to 1.15$)$ & 0.36 \\
Central nervous system cancer & 3 & 8,858 & M-H, fixed effect & $1.46(0.72$ to 2.96$)$ & 0.29 \\
Bone cancer & 2 & 5,858 & M-H, random effects & $1.00(0.06$ to 15.98$)$ & 1 \\
Stomach cancer & 2 & 6,244 & M-H, fixed effect & $0.84(0.50$ to 1.41$)$ & 0.51 \\
Pancreas cancer & 2 & 6,244 & M-H, fixed effect & $0.72(0.35$ to 1.47$)$ & 0.37 \\
Esophagus cancer & 2 & 6,244 & M-H, fixed effect & $0.73(0.29$ to 1.81$)$ & 0.49 \\
Colon cancer & 3 & 8,858 & M-H, fixed effect & $0.90(0.63$ to 1.29$)$ & 0.58 \\
Rectum cancer & 2 & 6,244 & M-H, fixed effect & $0.83(0.51$ to 1.35$)$ & 0.45
\end{tabular}

M-H = Mantel-Haenszel statistics.

standardized. The preferred value is urinary BMG measured in $\mu \mathrm{g} / \mathrm{g}$ creatinine, which is not significantly elevated (MD $=8.76,95 \% \mathrm{CI}-12.32$ to 29.84). Surprisingly, the uranium-exposed cohort has a significantly better creatinine clearance than the compared cohort (MD $=7.66$, $95 \%$ CI 0.12 to 15.20 ). 
Stammler et al.: Renal Effects and Carcinogenicity of Occupational Exposure to Uranium: A Meta-Analysis

Table 6. Renal biomarker differences of uranium-exposed persons

\begin{tabular}{llllll}
\hline Biomarker & $\begin{array}{l}\text { Included } \\
\text { trials }\end{array}$ & Participants & Statistical method & MD (95\% CI) & p value \\
\hline NAG, U/g creatinine & 4 & 439 & IV, fixed effect & $0.06(-0.12$ to 0.24$)$ & 0.52 \\
BMG, $\mu$ g/l urine & 3 & 563 & IV, fixed effect & $11.38(1.09$ to 21.68$)$ & 0.03 \\
BMG, $\mu$ g/g creatinine & 5 & 523 & IV, random effects & $8.76(-12.32$ to 29.84$)$ & 0.42 \\
Urinary glucose, g/day & 3 & 139 & IV, random effects & $0.03(-0.02$ to 0.08$)$ & 0.20 \\
Creatinine clearance, ml/min & 2 & 110 & IV, fixed effect & $7.66(0.12$ to 15.20$)$ & 0.05 \\
Total urinary protein, mg/day & 2 & 83 & IV, fixed effect & $6.70(-4.61$ to 18.02$)$ & 0.25 \\
Total urinary protein, mg/g creatinine & 3 & 393 & IV, fixed effect & $0.00(-0.26$ to 0.26$)$ & 0.98 \\
\hline
\end{tabular}

IV = Inverse-variance weighting.

Fig. 3. Funnel plot for the cancer

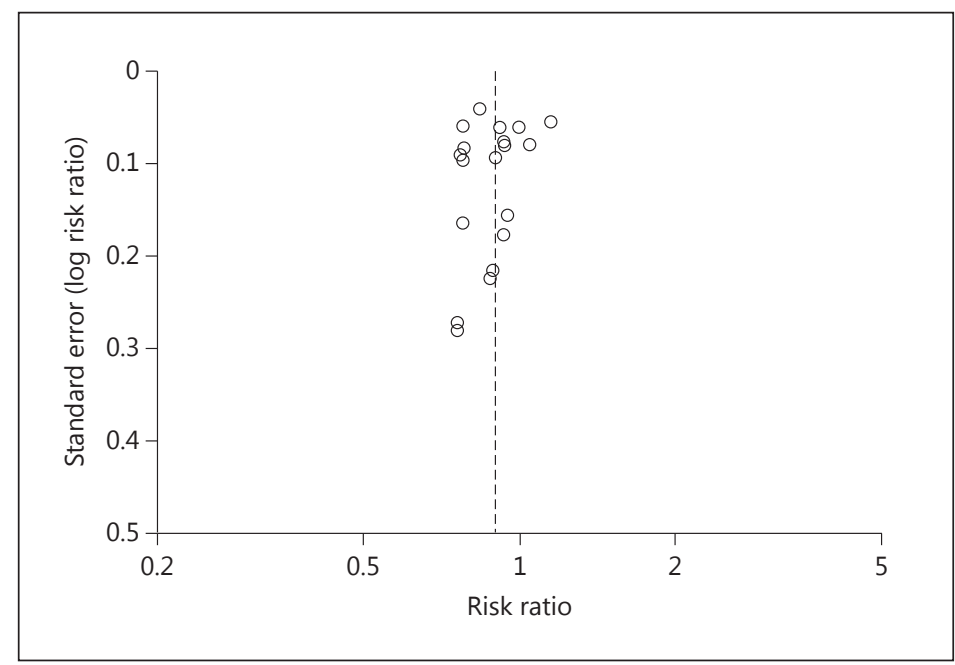
SMR of all malignant neoplasms.

\section{Discussion}

We found no significantly increased risk of cancer or nephrotoxicity in cohorts exposed to uranium. The nonsignificant results mainly reveal a reduced cancer risk. The SMR metaanalysis has the strongest explanatory power due to the large database. The question of bias has to be considered, though.

Causes of death are taken from national death certificates. To discuss the possibility of bias through incorrect death certificates, the SIR meta-analysis may help. With a maximum of only 3 clinical studies, the SIR analysis is not extensive enough to make insightful statements. But by comparing the SIR and SMR results, we can find no risk ratios varying in the opposite direction. This correlation speaks against a possible bias through incorrect death certificates.

Another bias could be resulting from conflicts of interest. Of the 19 studies, 6 are linked with the American Department of Energy and 5 with the Department of Defense or sponsored by uranium companies. If we remove these 11 possibly biased studies, we should observe an increase of the mortality rate in the case of a conflict of interest in national agencies. The SMR result of all malignant neoplasms, however, decreases from 0.90 (95\% CI 0.84 to 0.96$)$ to 0.88 ( $95 \%$ CI 0.81 to 0.96$)$ without these studies. Therefore, we may exclude the bias of a conflict of interest. 
Stammler et al.: Renal Effects and Carcinogenicity of Occupational Exposure to Uranium: A Meta-Analysis

There might remain bias that cannot be excluded. The first could be a possible publication bias. PubMed is a US American platform for citations. A look at the home countries of the studies found reveals only American-allied countries. There is for example no clinical study from China or Russia. Otherwise, there is an almost symmetrically distributed funnel plot for the cancer SMR of all malignant neoplasms (fig. 3).

Another bias may result from the integer number representation properties of RevMan 5.3, Cochrane's meta-analysis tool used for this article. We compared deaths of the uraniumexposed groups (integers) with standardized death rates of surrounding districts (point numbers) of the same group size. We had to round the point numbers for the meta-analysis tool. Especially in categories with a small amount of cancer deaths like in uterine, ovary or bone cancers, the rounding effect is noticeable. Another fact is that RevMan cannot estimate the risk ratio of studies with zero deaths in the uranium cohort and zero deaths (because of rounding) for the comparison group. Of the 5 uterine cancer studies introduced to the SMR meta-analysis, 3 are ignored for that reason.

To complete the bias analysis, we checked the 'healthy worker effect' mentioned e.g. for US American chemistry workers [18] and workers of the nuclear production complex of Hanford Site [19]. From 19 studies mentioned, we found 7 with SMR information for nonradiation workers. The average of the SMR of all malignant neoplasms of the nonradiation workers results in 0.99 , which means there is no difference in cancer deaths compared to home country rates, and therefore no healthy worker effect. The average SMR of the uraniumexposed cohort in these seven studies results in 0.84 .

The significantly decreased risk of the four mortality rates, one cancer incidence rate and the significantly better creatinine clearance for uranium-exposed workers, can be explained assuming that the health status might have been better protected by regular and detailed medical surveillance, especially for radiation workers.

These results can be used to help determining the risk and the toxicological profile of elemental uranium for humans. These findings are important for the uranium processing industry, showing that medical surveillance and the common safety standards are sufficient. But be aware that these results by no means change the hazardousness of the nuclear use of uranium and the fission products originating from it.

\section{Conclusion}

The SMR meta-analysis refutes the hypothesis that a chronically elevated uranium exposure is associated with an increased risk of cancer incidence or cancer mortality. Furthermore, if we stay below the acute toxicity limit of uranium, we can find no signs for acute or chronic kidney failure.

\section{References}

$>1$ McDiarmid MA, Albertini RJ, Tucker JD, Vacek PM, Carter EW, Bakhmutsky MV, Oliver MS, Engelhardt SM, Squibb KS: Measures of genotoxicity in Gulf war I veterans exposed to depleted uranium. Environ Mol Mutagen 2011;52:569-581.

2 Keith S, Faroon O, Roney N, Scinicariello F, Wilbur S, Ingerman L, Llados F, Plewak D, Wohlers D, Diamond G: Agency for Toxic Substances and Disease Registry (ATSDR) Toxicological Profiles. Agency for Toxic Substances and Disease Registry (US), 2009.

-3 Arzuaga X, Rieth SH, Bathija A, Cooper GS: Renal effects of exposure to natural and depleted uranium: a review of the epidemiologic and experimental data. J Toxicol Environ Health B Crit Rev 2010;13:527-545.

4 Walsh L, Grosche B, Schnelzer M, Tschense A, Sogl M, Kreuzer M: A review of the results from the German Wismut uranium miners cohort. Radiat Prot Dosimetry 2015;164:147-153. 
Stammler et al.: Renal Effects and Carcinogenicity of Occupational Exposure to

Uranium: A Meta-Analysis

5 Duport P: Is the radon risk overestimated? Neglected doses in the estimation of the risk of lung cancer in uranium underground miners. Radiat Prot Dosimetry 2002;98:329-338.

6 Kathren RL, Burklin RK: Acute chemical toxicity of uranium. Health Phys 2008;94:170-179.

7 Pavlakis N, Pollock CA, McLean G, Bartrop R: Deliberate overdose of uranium: toxicity and treatment. Nephron 1996;72:313-317.

8 Polednak AP, Frome EL: Mortality among men employed between 1943 and 1947 at a uranium-processing plant. J Occup Med 1981;23:169-178.

9 Spitz HB, Simpson JC, Aldridge TL: Analysis of uranium urinalysis and in vivo measurement results from eleven participating uranium mills. Prepared for U.S. Nuclear Regulatory Commission, DOI: 10.2172/6907594.

10 Center for Disease Control and Prevention: Fourth National Report on Human Exposure to Environmental Chemicals. 2015. p. 281.

-11 McDiarmid MA, Keogh JP, Hooper FJ, McPhaul K, Squibb K, Kane R, DiPino R, Kabat M, Kaup B, Anderson L, Hoover D, Brown L, Hamilton M, Jacobson-Kram D, Burrows B, Walsh M: Health effects of depleted uranium on exposed Gulf War veterans. Environ Res 2000;82:168-180.

-12 McDiarmid MA, Engelhardt S, Oliver M, Gucer P, Wilson PD, Kane R, Kabat M, Kaup B, Anderson L, Hoover D, Brown L, Handwerger B, Albertini RJ, Jacobson-Kram D, Thorne CD, Squibb KS: Health effects of depleted uraniumon exposed Gulf War veterans: a 10-year follow-up. J Toxicol Environ Health A 2004;67:277-296.

-13 McDiarmid MA, Engelhardt SM, Oliver M, Gucer P, Wilson PD, Kane R, Kabat M, Kaup B, Anderson L, Hoover D, Brown L, Albertini RJ, Gudi R, Jacobson-Kram D, Thorne CD, Squibb KS: Biological monitoring and surveillance results of Gulf War I veterans exposed to depleted uranium. Int Arch Occup Environ Health 2006;79:11-21.

14 McDiarmid MA, Engelhardt SM, Oliver M, Gucer P, Wilson PD, Kane R, Cernich A, Kaup B, Anderson L, Hoover D, Brown L, Albertini R, Gudi R, Jacobson-Kram D, Squibb KS: Health surveillance of Gulf War I veterans exposed to depleted uranium: updating the cohort. Health Phys 2007;93:60-73.

15 McDiarmid MA, Engelhardt SM, Dorsey CD, Oliver M, Gucer P, Wilson PD, Kane R, Cernich A, Kaup B, Anderson L, Hoover D, Brown L, Albertini R, Gudi R, Squibb KS: Surveillance results of depleted uranium-exposed Gulf War I veterans: sixteen years of follow-up. J Toxicol Environ Health A 2009;72:14-29.

-16 McDiarmid MA, Engelhardt SM, Dorsey CD, Oliver M, Gucer P, Gaitens JM, Kane R, Cernich A, Kaup B, Hoover D, Gaspari AA, Shvartsbeyn M, Brown L, Squibb KS: Longitudinal health surveillance in a cohort of Gulf War veterans 18 years after first exposure to depleted uranium. J Toxicol Environ Health A 2011;74:678-691.

-17 McDiarmid MA, Gaitens JM, Hines S, Breyer R, Wong-You-Cheong JJ, Engelhardt SM, Oliver M, Gucer P, Kane R, Cernich A, Kaup B, Hoover D, Gaspari AA, Liu J, Harberts E, Brown L, Centeno JA, Gray PJ, Xu H, Squibb KS: The Gulf War depleted uranium cohort at 20 years: bioassay results and novel approaches to fragment surveillance. Health Phys 2013;104:347-361.

18 Burns CJ, Bodner KM, Jammer BL, Collins JJ, Swaen GM: The healthy worker effect in US chemical industry workers. Occup Med (Lond) 2011;61:40-44.

19 Baillargeon J, Wilkinson GS: Characteristics of the healthy survivor effect among male and female Hanford workers. Am J Ind Med 1999;35:343-347.

-20 Baysson H, Laurier D, Tirmarche M, Valenty M, Giraud JM: Epidemiological response to a suspected excess of cancer among a group of workers exposed to multiple radiological and chemical hazards. Occup Environ Med 2000;57:188-194.

21 Beral V, Fraser P, Carpenter L, Booth M, Brown A, Rose G: Mortality of employees of the Atomic Weapons Establishment, 1951-1982. BMJ 1988;297:757-770.

22 Boice JD Jr, Cohen SS, Mumma MT, Chadda B, Blot WJ: A cohort study of uranium millers and miners of Grants, New Mexico, 1979-2005. J Radiol Prot 2008;28:303-325.

-23 Boice JD Jr, Cohen SS, Mumma MT, Ellis ED, Eckerman KF, Leggett RW, Boecker BB, Brill AB, Henderson BE: Updated mortality analysis of radiation workers at Rocketdyne (Atomics International), 1948-2008. Radiat Res 2011;176:244-258.

24 Chan C, Hughes TS, Muldoon S, Aldrich T, Rice C, Hornung R, Brion G, Tollerud DJ: Mortality patterns among Paducah Gaseous Diffusion Plant workers. J Occup Environ Med 2010;52:725-732.

-25 Dupree EA, Cragle DL, McLain RW, Crawford-Brown DJ, Teta MJ: Mortality among workers at a uranium processing facility, the Linde Air Products Company Ceramics Plant, 1943-1949. Scand J Work Environ Health 1987;13:100-107.

-26 Dupree-Ellis E, Watkins J, Ingle JN, Phillips J: External radiation exposure and mortality in a cohort of uranium processing workers. Am J Epidemiol 2000;152:91-95.

-27 Guseva Canu I, Cardis E, Metz-Flamant C, Caër-Lorho S, Auriol B, Wild P, Laurier D, Tirmarche M: French cohort of the uranium processing workers: mortality pattern after 30-year follow-up. Int Arch Occup Environ Health 2010;83:301-308.

-28 Hadjimichael OC, Ostfeld AM, D’Atri DA, Brubaker RE: Mortality and cancer incidence experience of employees in a nuclear fuels fabrication plant. J Occup Med 1983;25:48-61.

29 Kreuzer M, Dufey F, Laurier D, Nowak D, Marsh JW, Schnelzer M, Sogl M, Walsh L: Mortality from internal and external radiation exposure in a cohort of male German uranium millers, 1946-2008. Int Arch Occup Environ Health 2015;88:431-441.

-30 Loomis DP, Wolf SH: Mortality of workers at a nuclear materials production plant at Oak Ridge, Tennessee, 1947-1990. Am J Ind Med 1996;29:131-141. 
-31 McGeoghegan D, Binks K: The mortality and cancer morbidity experience of workers at the Capenhurst uranium enrichment facility 1946-95. J Radiol Prot 2000;20:381-401.

-32 McGeoghegan D, Binks K: The mortality and cancer morbidity experience of workers at the Springfields uranium production facility, 1946-1995. J Radiol Prot 2000;20:111-137.

33 National Institute for Occupational Safety and Health: Mortality patterns among uranium enrichment workers at the Portsmouth gaseous diffusion plant, Piketon, Ohio. NTIS Issue Number 200217 (2001).

34 Pinkerton LE, Bloom TF, Hein MJ, Ward EM: Mortality among a cohort of uranium mill workers: an update. Occup Environ Med 2004;61:57-64.

-35 Silver SR, Bertke SJ, Hein MJ, Daniels RD, Fleming DA, Anderson JL, Pinney SM, Hornung RW, Tseng CY: Mortality and ionising radiation exposures among workers employed at the Fernald Feed Materials Production Center (1951-1985). Occup Environ Med 2013;70:453-463.

-36 Stayner LT, Meinhardt T, Lemen R, Bayliss D, Herrick R, Reeve GR, Smith AB, Halperin W: A retrospective cohort mortality study of a phosphate fertilizer production facility. Arch Environ Health 1985;40:133-138.

-37 Zablotska LB, Lane RS, Frost SE: Mortality (1950-1999) and cancer incidence (1969-1999) of workers in the Port Hope cohort study exposed to a unique combination of radium, uranium and $\gamma$-ray doses. BMJ Open 2013; 3:e002159.

-38 Selden AI, Lundholm C, Edlund B, Hogdahl C, Ek BM, Bergstrom BE, Ohlson CG: Nephrotoxicity of uranium in drinking water from private drilled wells. Environ Res 2009;109:486-494.

-39 Thun MJ, Baker DB, Steenland K, Smith AB, Halperin W, Berl T: Renal toxicity in uranium mill workers. Scand J Work Environ Health 1985;11:83-90.

40 Zamora ML, Tracy BL, Zielinski JM, Meyerhof DP, Moss MA: Chronic ingestion of uranium in drinking water: a study of kidney bioeffects in humans. Toxicol Sci 1998;43:68-77.

-41 Zamora ML, Zielinski JM, Moodie GB, Falcomer RA, Hunt WC, Capello K:Uranium in drinking water: renal effects of long-term ingestion by an aboriginal community. Arch Environ Occup Health 2009;64:228-241. 